\title{
Study of influencing factors to chromophoric dissolved organic matter absorption properties from fluorescence features in Taihu lake in autumn
}

\author{
Chuang-Chun HUANG,${ }^{1 *}$ Yun-Mei LI, ${ }^{1}$ Hao YANG,,${ }^{1}$ De-Yong SUN, ${ }^{2}$ Liang-Jiang XU,${ }^{1}$ Xia CHEN ${ }^{1}$ \\ ${ }^{1}$ Key Laboratory of Virtual Geographic Environment, Nanjing Normal University, Nanjing; ${ }^{2}$ College of Remote Sensing, Nanjing \\ University of Information Science and Technology, Nanjing, China \\ *Corresponding author: huangchangchun_aaa@163.com
}

\begin{abstract}
In order to identify the components of chromophoric dissolved organic matter (CDOM), confirm the influence of components to the absorption coefficient of CDOM $\left(a_{C D O M}\right)$, and estimate $a_{C D O M}$ from fluorescence spectra, fluorescence and optical measurements of CDOM were carried out in November 2008. The results indicate that, the primary component of CDOM is humic-like. The secondary component is tryptophan-like, which is the product of phytoplankton and aquatic debris rather than the wastewater treatment drainaged from city. In this study, six fluorophores with multiple excitation-emission matrices (EEMs) peaks $(A, B, C, N, M, T)$ were identified according to the parallel factor analysis (PARAFAC). The average contribution of each component to the CDOM is 19.93, 18.82, 16.88, 16.39, 12.26, and 15.72\%, respectively. Red Shifted phenomenon will happen with the increase of fluorescence intensity for ultraviolet and terrestrially humic-like. Conversely, marine humic-like will appear Reverse Red Shifted with the increase of fluorescence intensity. The primary contributor to the shoulder value of CDOM's absorption coefficient at $275 \mathrm{~nm}$ is phytoplankton productivity, followed by marine humic-like. The main contributors to the shoulder shape are UV humic-like and phytoplankton productivity, followed by marine humic-like and tryptophan-like. A strong correlation between CDOM absorption and fluorescence intensity at emission wavelength of $424 \mathrm{~nm}$ and excitation wavelength ranging from 280 to $360 \mathrm{~nm}$ was found. The absorption coefficient can be retrieved successfully from the same excitation wavelength's fluorescence intensity by an exponential model.
\end{abstract}

Key words: chromophoric dissolved organic matter, fluorescence spectroscopy, parallel factor analysis (PARAFAC), remote sensing.

Received: July 2012. Accepted: January 2013.

\section{INTRODUCTION}

Chromophoric dissolved organic matter (CDOM) is the main light-absorbing component at wavelengths below 500 $\mathrm{nm}$ in many natural waters. It regulates the penetration of UV light into the water, and furthermore, mediates photochemical reactions (Mopper et al., 1991; Arrigo and Brown, 1996; Zepp et al., 1998; Toole and Siegel, 2004; Nelson et al., 2007). Consequently, CDOM is the most important biooptical factor regulating the exposure of planktonic organisms to ultraviolet (UV) radiation (Schindler et al., 1996). Additionally, light absorption by CDOM can reduce the photosynthetically active radiation available to phytoplankton and degrade the accuracy of chlorophyll estimates by satellite color sensors (Carder et al., 1989; Carder, 1991). Presently, the precision of CDOM retrieved from optical remote sensing is much low. The retrieval error of MODIS model is between -87.1 and $98.2 \%$ (Carder et al., 2003), and the error of Kowalczuk model is between -201.7 and $69.7 \%$ (Kowalczuk et al., 2005). Ocean colour models, pigment/primary-production algorithms and CDOM moniting could be improved by better knowledge of CDOM absorption properties and components. However, there is very little information about the variability of absorption and its composition, and few studies about the relationship be- tween absorption and fluorescence for CDOM in Taihu lake.

Three-dimensional fluorescence spectroscopy (3DEEM) is a popular method in the component identification of CDOM and algae for its high sensitivity and small interference (Mobed et al., 1996; McKnight et al., 2001; Patel-Sorrentino et al., 2002; Leenheer and Croué, 2003; Murphy et al., 2008). With the development of fluorescence sensor, fluorescence-to-absorption algorithms to retrieve $\mathrm{CDOM}$ absorption became more and more significative. Many researchers suggested that CDOM absorption coefficient could be retrieved from fluorescence measurements (Reuter et al., 1986; Donard et al., 1989; Ferrari and Tassan, 1991; Hoge et al., 1993) with high accuracy. The relationship between absorption coefficient and fluorescence intensity is a key step to retrieve CDOM absorption coefficient from fluorescence. Consequently, the study of CDOM composition, dynamic mechanism by the EEMs and the relationship between absorption coefficient and fluorescence intensity is very important, in the context of a global observation system, environmental protection or CDOM remote sensing.

Taihu lake is located in the Yangtze river delta (China; Fig. 1), which is one of the world's most heavily popu- 
lated regions with the highest rate of economic development in the last decade. The water quality in east lake and bay is much better than other areas. There is lots of aquatic vegetation in east lake and bay, and almost no algal bloom occurred in this area. The dynamic ratio [(square root of area)/depth] of Taihu lake can reach 25.4. Waters in Taihu lake are consistently highly turbid caused by monsoon-induced sediment resuspended (Bachmann et al., 2000). In recent years, various pollutants, such as surrounding industrial and agricultural wastes, and residential wastewater drainage, had significantly contaminated the lake. Large areas of algae bloom caused by attendant eutrophication of the lake have been present for many years (Qin et al., 2004). Taihu lake provides normal water usage for several million residents nearby Wuxi City. Algae-polluted waters in the lake have affected and interrupted the normal life of the several million residents nearby. In this study, 3DEEM combined with parallel factor analysis (PARAFAC) was applied to identify CDOM compositions and fluorescence property of CDOM. Then, the influence of components to absorption coefficient of CDOM $\left(a_{\mathrm{CDOM}}\right)$ was confirmed and the estimate model of $a_{\text {CDOM }}$ from fluorescence spectroscopy was established.

\section{METHODS}

\section{Information of study area}

Taihu lake is a typical shallow inland eutrophic lake located between $30^{\circ} 90^{\prime}-31^{\circ} 54^{\prime} \mathrm{N}$ and 119 $553^{\prime}-$ $120^{\circ} 596^{\prime} \mathrm{E}$. It is the third largest freshwater lake in China with an area of $2428 \mathrm{~km}^{2}$ (water surface area is $2338 \mathrm{~km}^{2}$, island area is $90 \mathrm{~km}^{2}$ ), and a mean depth of $1.9 \mathrm{~m}$ (Qin et al., 2004). In this eutrophic region, algal blooms take place regularly over an area of about $132 \mathrm{~km}^{2}$ every year. Samples were collected in Taihu lake in November 2008. During the cruise, optical measurements were made, and water samples were taken at a total of 57 sites (Fig. 1).

\section{Measurement of absorption coefficients}

Water from 0-0.5 m depth was collected in $2 \mathrm{~L}$ acidcleaned plastic bottles and kept in ice while in the field. Water samples were first filtered through a $47 \mathrm{~mm}$ diameter Whatman fiberglass GF/F filter (Whatman Ltd., Maidstone, UK) with $0.70 \mu \mathrm{m}$ pores, and then refiltered through a $25 \mathrm{~mm}$ diameter Millipore filter (Millipore, Billerica, MA, USA) with $0.22 \mu \mathrm{m}$ pores. The absorption spectra of the filtered water were measured between 240 and $800 \mathrm{~nm}$ at $1 \mathrm{~nm}$ interval using a Shimadzu UV2550PC UV-Visible spectrophotometer (Shimadzu Corporation, Kyoto, Japan) with $1 \mathrm{~cm} \times 4 \mathrm{~cm}$ quartz cuvette, in which Milli-Q water (Millipore) was used as reference. The absorption coefficient of CDOM was obtained using the following equation (Bricaud et al., 1981):

$$
a_{C D O M}\left(\lambda^{\prime}\right)=2.303 D(\lambda) / r
$$

where $a_{\mathrm{CDOM}}\left(\lambda^{\prime}\right)$ is the uncorrected CDOM absorption coefficient at wavelength $\lambda ; \mathrm{D}(\lambda)$ is the optical density at

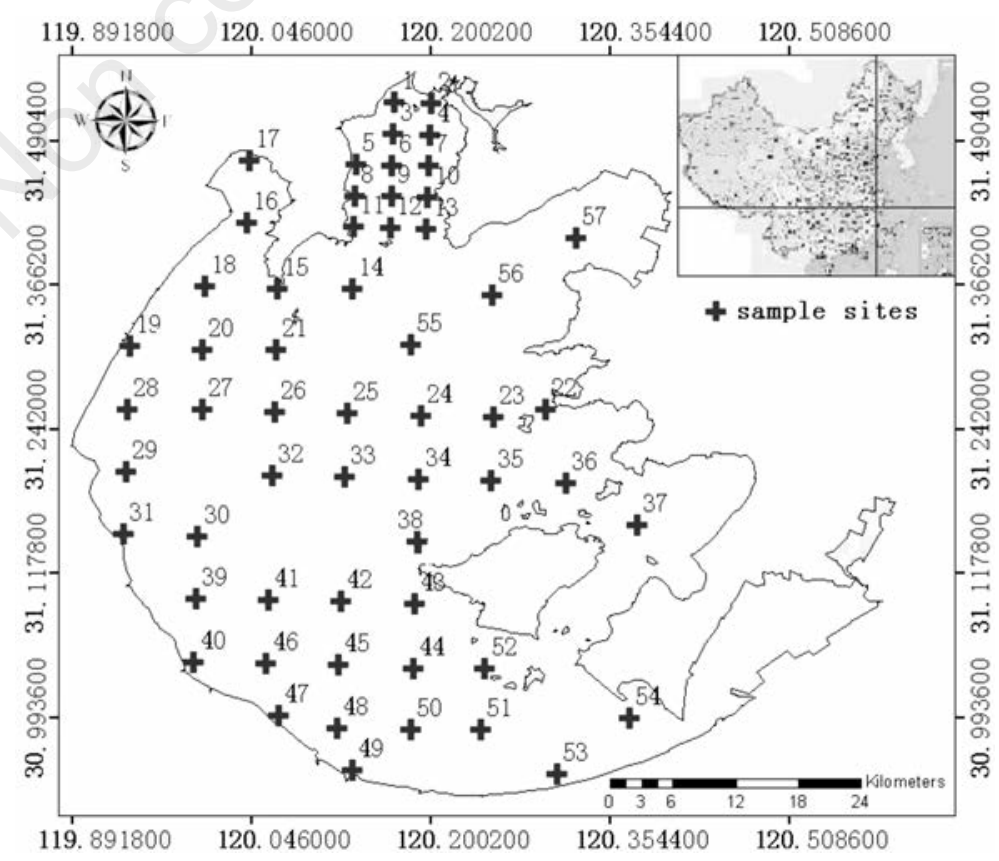

Fig. 1. Distribution of sample stations in the study area (the figure in top right corner shows the position of Taihu lake in China). 
wavelength $\lambda$; and $\mathrm{r}$ is the cuvette light path length in $\mathrm{m}$. The absorption coefficient was corrected for backscattering of small particles and colloids that had passed through the filters using the following equation (Bricaud et al., 1981; Green and Blough, 1994; Keith et al., 2002):

$a_{C D O M}(\lambda)=a_{C D O M}\left(\lambda^{\prime}\right)-a_{C D O M}\left(750^{\prime}\right) \lambda / 750$ (eq. 2$)$

where $a_{\mathrm{CDOM}}(\lambda)$ is the absorption coefficient at a given wavelength $(\lambda)$ that has been corrected for scattering, and $a_{\text {СDOM }}\left(750^{\prime}\right)$ is the uncorrected absorption coefficient at $750 \mathrm{~nm}$

Bricaud et al. (1981) and Twardowski et al. (2004) proposed the following expression for simulating the CDOM absorption spectra:

$$
a_{C D O M}(\lambda)=a_{C D O M}\left(\lambda_{0}\right) \exp \left[S_{C D O M}\left(\lambda_{0}-\lambda\right)\right] \text { (eq. 3) }
$$

where $a_{\mathrm{CDOM}}(\lambda)$ is the CDOM absorption coefficient at $\lambda$ wavelength $\left(\mathrm{m}^{-1}\right) ; \lambda_{0}$ is the reference wavelength $(\mathrm{nm})$, and $S_{\text {CDOM }}$ is the spectral slope of $a_{\text {CDOM }}(\lambda)$ spectrum $\left(\mathrm{nm}^{-1}\right)$. Then, the spectral slope of CDOM is estimated using the least squares method according to this equation.

\section{Measurement of fluorescence}

Fluorescence excitation-emission matrices (EEMs) spectra were measured with a LS-50B fluorescence spectrophotometer (Perkin-Elmer Inc., Waltham, MA, USA). Excitation-emission matrices spectra were gathered with subsequent scanning emission spectra from 250 to 700 $\mathrm{nm}$ at $0.5-\mathrm{nm}$ increments by varying the excitation wavelength from 200 to $440 \mathrm{~nm}$ at 5 -nm increments. The spectra were recorded at a scan rate of $1200 \mathrm{~nm} / \mathrm{min}$, using excitation and emission slit bandwidths of $10 \mathrm{~nm}$. The fluorescence intensity corrected by emission signals to excitation power was recorded. The blank water [(Milli-Q water, $18 \mathrm{M} \Omega \cdot \mathrm{cm}$ (Millipore)] scans were performed at intervals of 10 analyses. The Raman peak of water at an excitation of $348 \mathrm{~nm}$ was used to test machine stability.

\section{Parallel factor analysis model}

Fluorescence EEMs were modeled using PARAFAC which uses an alternating least squares algorithm to minimise the sum of squared residuals across the dataset and, in so doing, enables estimation of the underlying structure of the EEMs (Harshman and Lundy, 1994; Bro, 1997). The data signal is decomposed into a set of trilinear terms and a residual array:

$$
\begin{gathered}
X_{\mathrm{ijk}}=\sum_{f=1}^{F} c_{\mathrm{if}} b_{\mathrm{jf}} a_{\mathrm{kf}}+\sigma_{\mathrm{ijk}} \\
i=1 \ldots . . I ; j=1 \ldots . . J ; k=1 \ldots . . K
\end{gathered}
$$

where $X_{\mathrm{ijk}}$ is the intensity of the $i^{\text {th }}$ sample at the $j^{\text {th }}$ variable (emission mode) and at the $k^{\text {th }}$ variable (excitation mode) in the F-component model; $c_{\text {if }}$ is the concentration of the $f^{\text {th }}$ analyte in the $i^{\text {th }}$ sample, $b_{\mathrm{jf}}$ is the relative emission of analyte $f$ at emission $j$ and $a_{\mathrm{kf}}$ is the relative absorption at excitation $k$, and $\mathrm{s}_{\mathrm{ijk}}$ is the residual noise, representing the variability not accounted for by the model.

$$
\mathrm{SSR}=\sum_{i=1}^{I} \sum_{j=1}^{J} \sum_{k=1}^{K} \sigma_{\mathrm{ijk}}^{2}
$$
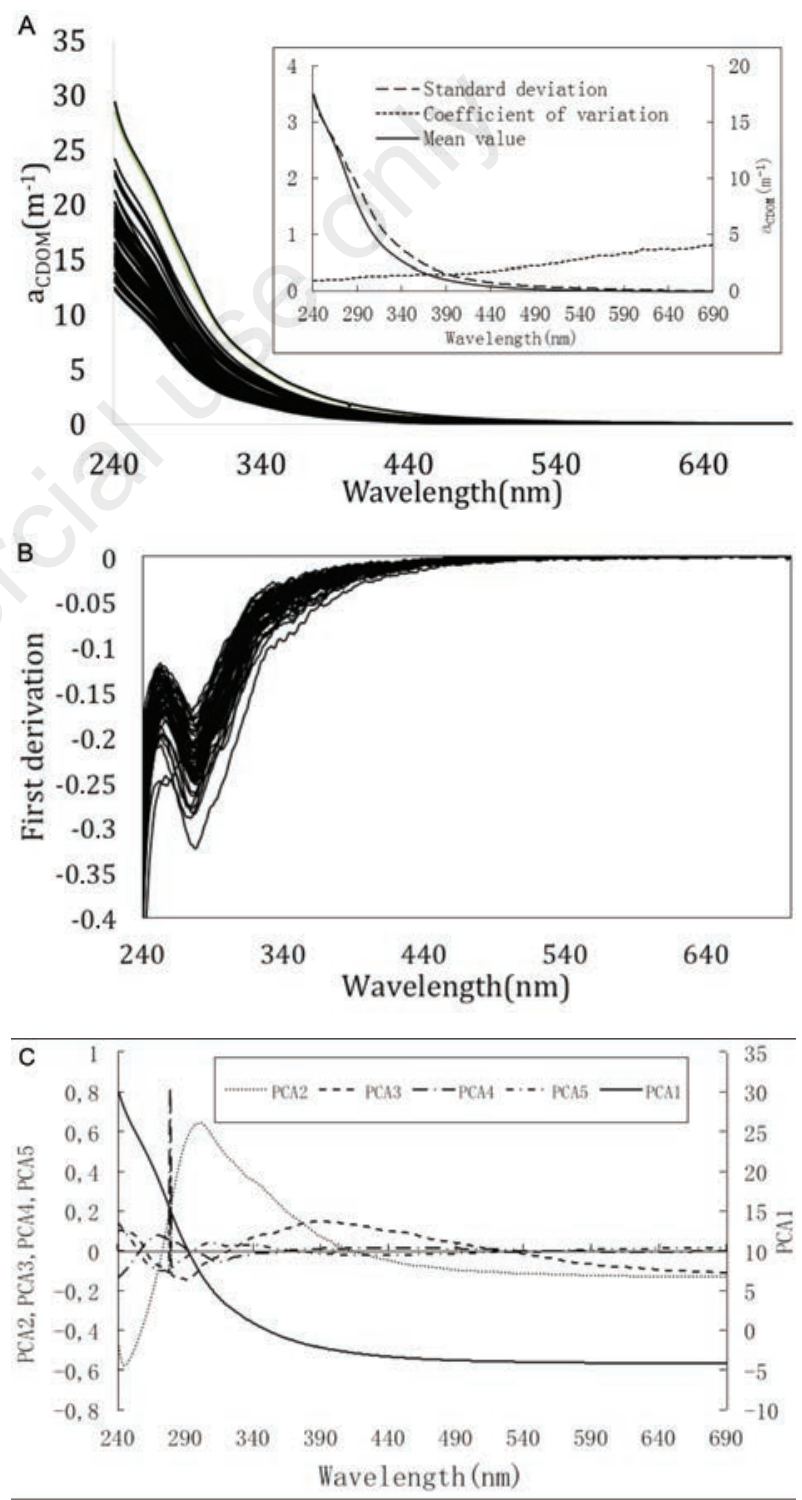

Fig. 2. A, Chromophoric dissolved organic matter absorption spectra $\left(a_{\mathrm{CDOM}}\right)$ in Taihu lake (the figure in top right corner shows the average value, standard deviation and variation coefficient of $a_{\mathrm{CDOM}}$ at total sample sites in Taihu lake); $\mathrm{B}$, first derivative of $a_{\mathrm{CDOM}} ; \mathrm{C}$, results of the principal component analysis. 
First, determine the component number $F$, initialisation of $a$ and $b$, estimate value of $c$; second, estimate $a$ from value $b$ and $c$; third, estimate $b$ from $a$ and $c$; repeat above three steps until the SSR reach the convergent standard. In this paper, the convergent standard is $10^{-6}$.

\section{RESULTS}

\section{Chromophoric dissolved organic matter absorption}

A wide range of variability in CDOM absorption was found in Taihu lake. $a_{\mathrm{CDOM}}(325)$ is ranging from 2.28 to $6.94 \mathrm{~m}^{-1}, a_{\mathrm{CDOM}}(375)$ is ranging from 0.782 to $2.896 \mathrm{~m}^{-1}$, and $a_{\mathrm{CDOM}}(440)$ is ranging from 0.169 to $1.014 \mathrm{~m}^{-1}$. The mean values of $a_{\mathrm{CDOM}}$ (325), $a_{\mathrm{CDOM}}(375)$ and $a_{\mathrm{CDOM}}(440)$ are $3.536,1.368$, and 0.450 , and the coefficients of variation are $27.37,29.51$, and $34.88 \%$, respectively. Chromophoric dissolved organic matter absorption spectra exponentially decrease with wavelength (Fig. 2A). Little irregularities on the absorption, which may have important effects on the calculation of absorption spectral shape $(S)$, were found through the first-derivative transformation (Fig. 2B). Previous studies suggested that a peak at approximately 334 $\mathrm{nm}$ will appear in the CDOM absorption spectra due to amino acids (MAAs) absorption from phytoplankton (Vernet and Whitehead, 1996). However, there is slight fluctuation at approximately $334 \mathrm{~nm}$ in this study. A flat peak, which might be associated with the absorption by proteins and nucleic acids (Bidigare, 1989; Laurion et al., 2000), was found at approximately $275 \mathrm{~nm}$. There may be two reasons for this: first, there were small numbers of phytoplankton in studied water; second, damage of phytoplankton cell was avoided by using low pressure during filtration.

The principal component analysis (PCA) was used to assess the variation of $a_{\mathrm{CDOM}}$ (Fig. 2C). The first principal component (PCA1) can explain $99.88 \%$ variation of CDOM absorption coefficient. Consequently, there is no significant change of CDOM compositions among all sample sites. This background excluded, the second principal component (PCA2) can explain 0.099\% variation, especially around $315 \mathrm{~nm}$. The third principal component (PCA3) relates to the variation of CDOM in the range of 350 to $500 \mathrm{~nm}$. The fourth principal component (PCA4) mainly expresses the variation of CDOM at $275 \mathrm{~nm}$. The explained variation of the fifth principal component (PCA5) is so small that it can be neglected.

\section{Fluorescence characteristics of chromophoric dissolved organic matter}

The EEMs spectra of all sample sites (57) can be expressed as three typical patterns (Fig. 3). Strong fluorescence at Ex 250 nm, Em 420 nm, and Ex 340 nm, Em 430 $\mathrm{nm}$ characterised UV humic-like (peak A) and visible humic-like. They include terrestrial humic-like and marine humic-like (peaks $\mathrm{C}$ and $\mathrm{M}$ ) (Figs. 3A and 3B). Ter-
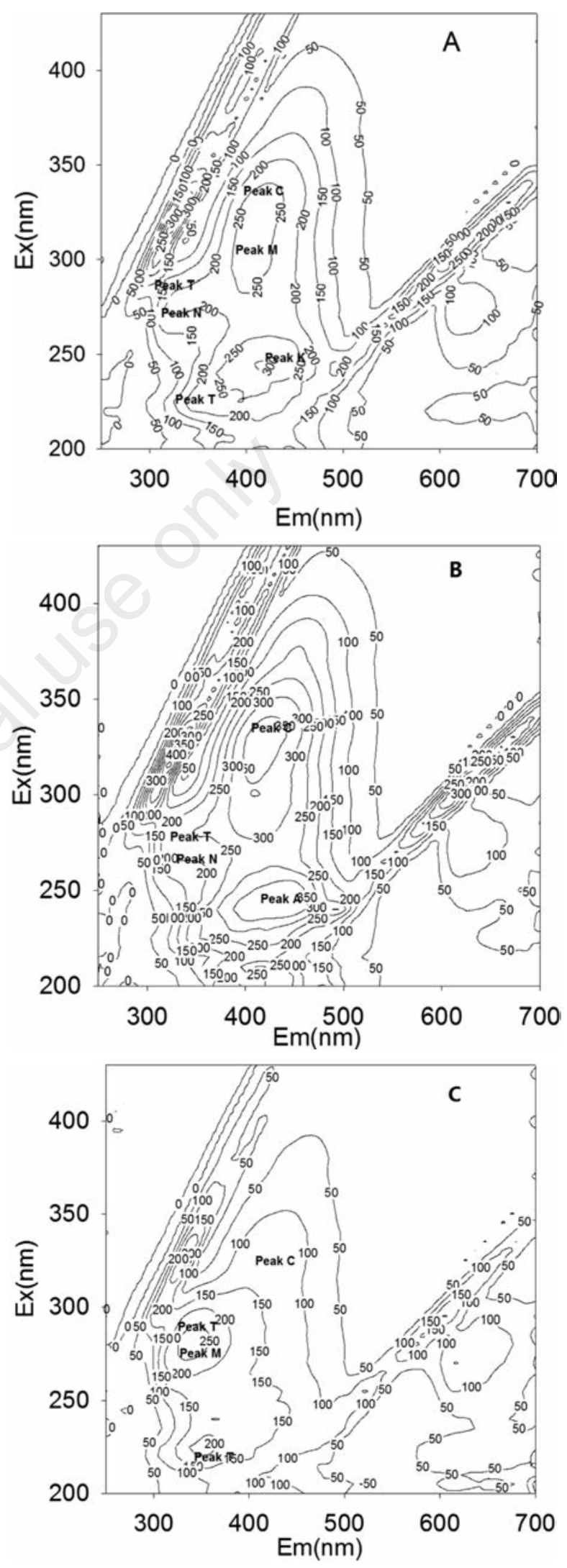

Fig. 3. Total fluorescent peaks identified by three typical styles excitation-emission matrices. 
restrial humic-like (peak C) can be used to indicate the terrestrial source of CDOM. The marine humic-like (peak M) displayed strong fluorescence at Ex $250 \mathrm{~nm}$, Em $370 \sim 420 \mathrm{~nm}$, with traces of the autochthonous source of CDOM. These three peaks demonstrate that both terrestrial and autochthonous CDOM occurred in Taihu lake, but the terrestrial was the primary contributor to CDOM. In ocean research, peaks $\mathrm{A}$ and $\mathrm{C}$ identified as terrestrial organic matter could be traced in the open ocean (Pacific and Atlantic) at levels of approximately $1.5 \%$ of riverine concentrations, while peak $\mathrm{M}$ is identified as marine resource (autochthonous) (Murphy et al., 2008).

There are other three key fluorescence peaks commonly observed in freshwater aquatic samples, besides the above mentioned three peaks. These have been classified according to Coble (1996) and Coble et al. (1998), Stedmon et al. (2003), and Stedmon and Markager (2005a, 2005b) as follows: i) peak B, tyrosine-like (Ex/Em, 225-237/309-321 nm and Ex/Em, 275/310 nm); ii) peak T, tryptophan-like (Ex/Em, 225-237/340-381 nm and $\mathrm{Ex} / \mathrm{Em}, 275 / 340 \mathrm{~nm}$ ); iii) peak N, undefined (associated with phytoplankton productivity) (Ex/Em, 280/370 $\mathrm{nm})$. Excitation-emission matrices acquired from CDOM in Taihu lake exhibit peak T clearly, but not peak B or N. The intensity of peak $\mathrm{M}$ is so strong that the signal of peak $\mathrm{N}$ is covered by peak M (Fig. 3C).

The fluorescent peaks position and intensity were extracted from the EMMs according the classified peaks via the Matlab software. The autocorrelation between each peak is very strong (Tab. 1). Peak T has a strong correlation with peaks $\mathrm{N}$ and $\mathrm{M}$, and low correlation with peak C. Because peak $\mathrm{N}$ and peak $\mathrm{M}$ are associated with phytoplankton, it can be concluded that peak T (tryptophanlike) is produced by phytoplankton debris (i.e. may include some aquatic organism) and not by the wastewater treatment drained from the city. The ratio of peak A to peak $\mathrm{C}\left(\Phi=I_{\mathrm{A}} / I_{\mathrm{C}}\right)$ can be used to express the structure and maturation degree of organic matter (Coble, 1996), and to indicate the sources of organic matter precursors in lakes and rivers as well (McKnight et al., 2001). According to McKnight et al. (2001), microbially-derived fulvic acids exhibit a higher ratio $(\sim 1.9)$ than terrestrially-derived fulvic acids ( 1.3). In this paper, $\Phi$ range is from 1.012 to
1.879, which is bigger than 1.76 1.97 in Baihua and Hongfeng lakes and smaller than 1.55-2.30 in rivers (Fu et al., 2007). The mean value of $\Phi$ is 1.287 which is close to the 1.26 in CuiCui lake (Coble, 1996), where terrestrially-derived fulvic acids are the primary source of CDOM. The coefficient of variation of $\Phi$ is $19.924 \%$.

Additionally, the emission positions of peaks A, C, M are strongly correlated with their intensity $\left(\mathrm{R}^{2}=0.6604\right.$, $\left.\mathrm{P} \leq 0.01 ; \mathrm{R}^{2}=0.5614, \mathrm{P} \leq 0.05 ; \mathrm{R}^{2}=-0.567, \mathrm{P} \leq 0.05\right)$. Peaks A and $\mathrm{C}$ show the red rhifted phenomenon with the increase of fluorescence intensity. In contrast, peak $\mathrm{M}$ shows the reverse red shifted phenomenon. This phenomenon is associated with the EMMs data in Fig. 3.

\section{Parallel factor analysis}

All PARAFAC analyses were performed in MATLAB 7.1 (Mathworks, Natick, MA, USA) using the N-way toolbox version 3.10 (Andersson and Bro, 2000). The explained variations were $89.02,92.48,94.87,96.36$ and $97.27 \%$ for component numbers ranging from 2 to 12 , respectively (Fig. 4A). The (PCA) was used to check the contribution percentage of $\mathrm{PC}$ to the total explained variation (Figs. 4A, 4B and 4C). By optimising calculation speed and explained variation, the optimal number of components was set to 6 for this model.

The EEMs $\left[901\left(1_{\mathrm{Em}}\right.\right.$ number $) \times 48\left(1_{\mathrm{Ex}}\right.$ number $) \times 57(\mathrm{sam}$ ple sites)] were decomposed into 6 primary components (PC1 PC6) by the PARAFAC model (Fig. 4). The PC1 is the humic-like including UV humic-like (peak A) and visible humic-like (peak C and peak M). The PC2 is mainly Protein-like (tryptophan-like, peak T), especially at 275/340 (Ex/Em). The PC3, PC4, PC6 are protein-like (Tyrosine-like, peak B) at 280/305-310, peak N (associated with phytoplankton productivity), and peak T. Fluorescent technology benefits to discover these fluorophores (Chen et al., 2003), as defined by Stedmon (2007). These kinds of fluorophores mainly are the small particle organisms, and their molecule weight is smaller than $1.0 \mathrm{KDa}$ (Sleighter and Hatcher, 2008; Helms et al., 2008). The PC5 is the fluorophore of photochemical production for high molecule weight (mainly ranging from 1.0 to 3.0 $\mathrm{KDa}$ ) terrestrially humic-like.

The $\mathrm{c}$ result coefficient $c_{\mathrm{if}}$ was used to calculate the

Tab. 1. The correlative matrix of fluorophores.

\begin{tabular}{|c|c|c|c|c|c|c|}
\hline Peaks & A & B & $\mathrm{C}$ & $\mathrm{N}$ & M & $\mathrm{T}$ \\
\hline A & 1 & & & & & \\
\hline B & 0.608696 & 1 & & & & \\
\hline $\mathrm{C}$ & 0.810918 & 0.309722 & 1 & & & \\
\hline $\mathrm{N}$ & 0.888121 & 0.788004 & 0.721874 & 1 & & \\
\hline M & 0.891694 & 0.684873 & 0.815672 & 0.949418 & 1 & \\
\hline $\mathrm{T}$ & 0.828833 & 0.860567 & 0.604711 & 0.906756 & 0.888393 & 1 \\
\hline
\end{tabular}



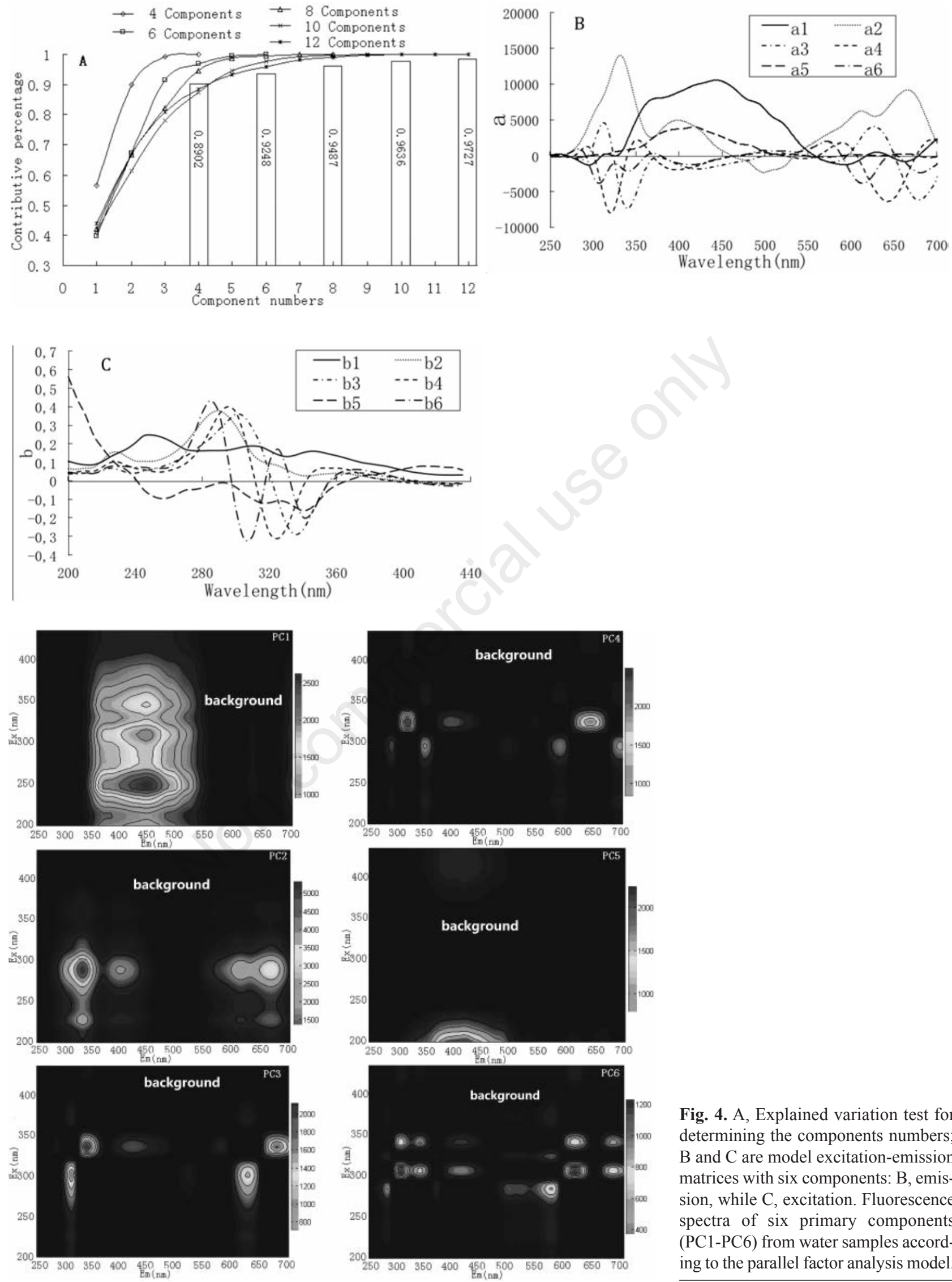

Fig. 4. A, Explained variation test for determining the components numbers; $\mathrm{B}$ and $\mathrm{C}$ are model excitation-emission matrices with six components: $\mathrm{B}$, emission, while $\mathrm{C}$, excitation. Fluorescence spectra of six primary components (PC1-PC6) from water samples according to the parallel factor analysis model. 
contribution percentage of primary component to EEMs, as: $\Psi=\operatorname{abs}\left(c_{\text {if }}\right) \backslash \Sigma \operatorname{abs}\left(c_{\text {if }}\right)(\mathrm{f}=1,2,3,4,5,6)$, the percentage contributed by PC1 to PC6 are 19.93, 18.82, 16.88, 16.39, 12.26 , and $15.72 \%$, respectively.

\section{Effect of components on absorption coefficient of chromophoric dissolved organic matter $(275 \mathrm{~nm})$}

A shoulder value was found at approximately $275 \mathrm{~nm}$ [ $\left.a_{\text {CDOM }}(275 \mathrm{~nm})\right]$ in Taihu lake (Bidigare, 1989; Laurion et al., 2000; Bontempi et al., 2004; Repetad et al., 2004; Kieber et al., 2007), which also appeared in the data of Zhao and Qin (2008) and Warnock and Gieskes (1999). This shoulder value destroys the consistency of CDOM exponential decrease with wavelength. Therefore, many researchers had divide the whole wavelength range into different sets to calculate $S_{\mathrm{CDOM}}$. Presently, there is unclear quantitative explanation of this shoulder's dynamic mechanism. In this work, besides the remarkable correlation between peak $\mathrm{C}$ and $a(275 \mathrm{~nm})$ (Fig. 5, unbroken line) $\left(\mathrm{R}^{2}=0.9369, \mathrm{P} \leq 0.0001\right)$, there still exists a significant relationship between $a(275 \mathrm{~nm})$ and peaks A, N, M, T $\left(\mathrm{R}^{2}=0.7628, \mathrm{P} \leq 0.001 ; \mathrm{R}^{2}=0.6570, \mathrm{P} \leq 0.005 ; \mathrm{R}^{2}=0.7590\right.$, $\left.\mathrm{P} \leq 0.001 ; \mathrm{R}^{2}=0.5451, \mathrm{P} \leq 0.05\right)$. The contributions of peaks A, C, N, M, T to $a(275 \mathrm{~nm})$ are $2.77,83.15,8.68,3.86$ and $1.55 \%$, respectively, obtained through normal multiple linear regression. The shape of this shoulder (expressed as the first derivative value at $275 \mathrm{~nm}$ ) is remarkably correlated to peak $\mathrm{C}$ (Fig. 6, dashed) $\left(\mathrm{R}^{2}=-0.9215, \mathrm{P} \leq 0.0001\right)$ and peaks $\mathrm{A}, \mathrm{N}, \mathrm{M}, \mathrm{T}\left(\mathrm{R}^{2}=-0.71381, \mathrm{P} \leq 0.001 ; \mathrm{R}^{2}=-0.5737, \mathrm{P} \leq 0.005\right.$; $\left.\mathrm{R}^{2}=-0.6744, \mathrm{P} \leq 0.001 ; \mathrm{R}^{2}=-0.45495, \mathrm{P} \leq 0.05\right)$. The contributions of peaks A, C, N, M, T to the first derivative value at $275 \mathrm{~nm}$ are $9.39,70.91,9.21,4.70$, and $5.79 \%$, respectively. It can be seen that peak $\mathrm{C}$ is the mainly influencing factor to the value and shape of the shoulder. Excluding this background factor (peak $\mathrm{C}$ is the primary influencing factor to the total samples in the whole wavelength range in Taihu

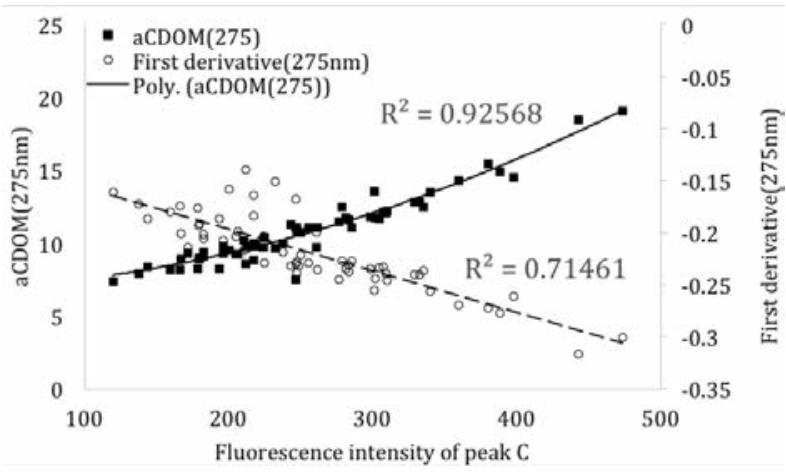

Fig. 5. Relationship between the first derivation value, absorption coefficient and peak $\mathrm{C}$. lake), $a(275 \mathrm{~nm})$ is the primary affected by peak $\mathrm{N}$ (associated with phytoplankton productivity), followed by peak $\mathrm{M}$. The shape of the shoulder is primary affected by peak $A$ and $\mathrm{N}$, followed by peaks $\mathrm{T}$ and $\mathrm{M}$.

\section{Relationship between absorption and fluorescence}

This study found a strong correlation between CDOM absorption and fluorescence intensity at the $424 \mathrm{~nm}$ emis-
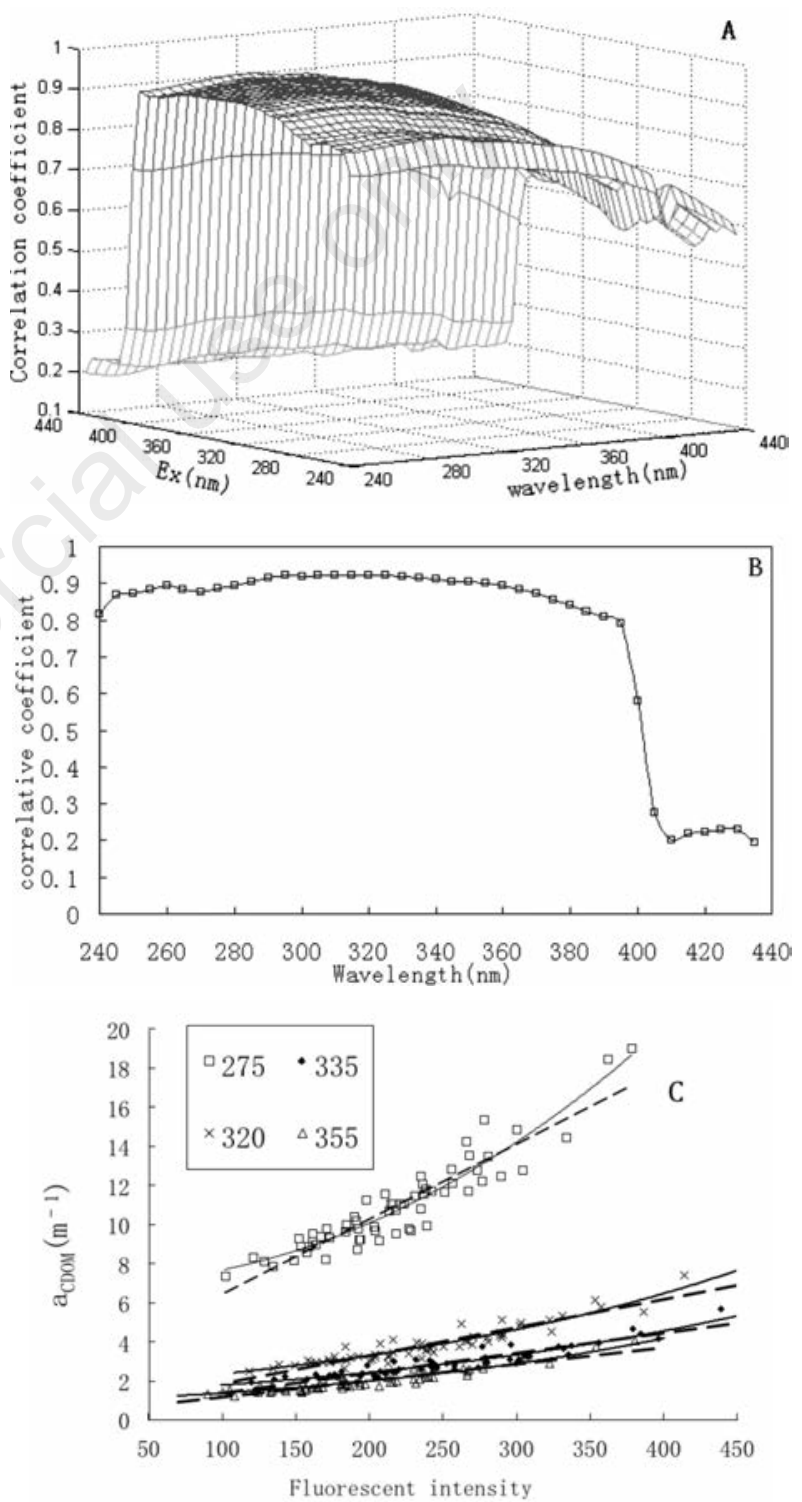

Fig. 6. A, Correlation coefficients between absorption (240 400 $\mathrm{nm})$ and fluorescence intensity (Ex/Em, 240 440 nm/424 nm); $\mathrm{B}$, diagonal representation of $\mathrm{A}$, i.e. the position (wavelength) of absorption and fluorescent is the same; $\mathrm{C}$, relationship between absorption and fluorescence: the unbroken line is the exponential model, while the dashed line represents the linear model. 
sion wavelength (Fig. 6A), which is close to the traditional emission wavelength of $450 \mathrm{~nm}$. The correlation coefficient decreases with increasing absorption wavelength (240 440 $\mathrm{nm}$ ) in the range of all excitation wavelengths (240 440 $\mathrm{nm})$. The biggest correlation coefficient is around $355 \mathrm{~nm}$. This result is same as with traditional excitation wavelength and Hoge et al.'s (1993) research, where $355 \mathrm{~nm}$ corresponds to reliable high power pulsed UV laser lines available for both shipboard and airborne fluorescence spectroscopy of CDOM. The diagonal of correlative matrix was extracted (Fig. 6B) according to Hoge et al.'s (1993) research (if reliable $a_{\mathrm{CDOM}}$ values are to be retrieved from fluorescence measurements, the absorption coefficients must be measured at the same wavelength used to stimulate fluorescence). The correlation coefficientin the rangingof $280-360 \mathrm{~nm}$ is bigger than other wavelength region. A model of $a_{\mathrm{CDOM}}$ was established by fluorescence intensity at 280, 320, 335 and $355 \mathrm{~nm}$ (Fig. 6C; Tab. 2). The wavelengths of UV-B are 280 and $320 \mathrm{~nm}$, and these two values are important to estimate the $a_{\mathrm{CDOM}}$ and diffuse attenuation coefficient $\left(K_{\mathrm{d}}\right)$ in the whole UV-B wavelength range. Moreover, $335 \mathrm{~nm}$ is close to the nitrogen laser wavelength. In this study area, $a_{\mathrm{CDOM}}$ has stronger exponential relationship to fluorescence intensity than linear, although the linear model is much more popular (Zhang et al., 2005, 2007a, 2007b; Hoge et al., 1993).

This relationship can be also used to calculate the fluorescence intensity, giving insight into sources and composition of CDOM, from the absorption coefficient, if we can successfully retrieve the absorption coefficient from satellite data (Lee et al., 2002). Consequently, we can trace CDOM sources and quantificationally estimate CDOM composition of from the satellite data.

\section{DISCUSSION}

Chromophoric dissolved organic matter includes humic acids, fulvic acids, proteins and various types of hydrophilic organic acids, carboxylic acids, amino acids, carbohydrates and so on. Fluorescence properties of CDOM are covered by its components and functional groups, as well as their dynamic characteristics, which result into re- markable spatial-temporal variations of fluorescence intensity. At the same time, the humic-like peak presents the red shifted, so that the fluorescent position and intensity in the remote sensing data are hard to be identified and increase the difficulty of fluorescent remote sensing applications. Additionally, the fluorescent remote sensing is not suitable when CDOM fluorescence signal is covered by the phytoplankton or nonpigment matter in eutrophic or very turbid inland water. The fluorescent algorithm is an important method to retrieve $a_{\mathrm{CDOM}}$ in the ocean colour remote sensing, but uncertainties in fluorescent algorithm should be addressed to applying the method to case 2 water or to much more complex water bodies.

\section{CONCLUSIONS}

Several important conclusions can be drawn from the above analysis of CDOM. First, the components of CDOM in Taihu lake are very complex, and the humic-like (i.e. UV humic-like and visible humic-like) is the primary component; the tryptophan-like is primarily produced by phytoplankton and aquatics' debris not by wastewater drainage. Second, peaks A and $\mathrm{C}$ have the red shifted phenomenon with increasing fluorescence intensity; in contrast, peak M has the reverse red shifted phenomenon. Third, the EEMs can be decomposed into six primary components and they can explain $92.48 \%$ variation. The average contribution of each primary component to the EEMs is $19.93,18.82$, $16.88,16.39,12.26$ and $15.72 \%$, respectively. Fourth, excluding the background influencing factor peak $\mathrm{C}$, the primary contributor to the shoulder value of CDOM's absorption coefficient is peak $\mathrm{N}$, followed by peak $\mathrm{M}$. The main contributor to the shoulder shape are peaks A and N, followed by peaks $\mathrm{M}$ and T. Last, a strong correlation between CDOM absorption and fluorescence intensity at the emission wavelength of $424 \mathrm{~nm}$ and excitation wavelength ranging from 280 to $360 \mathrm{~nm}$ was found, and the wavelength can be used to retrieve $a_{\mathrm{CDOM}}$.

\section{ACKNOWLEDGMENTS}

This research was supported by: the National Science and Technology Support Project of China (No.41201325;

Tab. 2. Regression equations for absorption and fluorescence data sets $(\mathrm{P}<0.0001)$.

\begin{tabular}{lccc}
\hline Wavelengths $(\mathrm{nm})$ & Equation & $\mathrm{R}^{2}$ & $\mathrm{~F}$ \\
\hline 275 & $a(275)=5.2663 \times \operatorname{EXP}[0.0033 \times \mathrm{Fn}(275)]$ & 0.876 & 423.42 \\
& $a(275)=0.0383 \times \operatorname{Fn}(275)+2.6330$ & 0.854 & 352.27 \\
320 & $a(320)=1.6853 \times \operatorname{EXP}[0.0034 \times \mathrm{Fn}(320)]$ & 0.901 & 545.92 \\
& $a(320)=0.0145 \times \operatorname{Fn}(320)+0.4194$ & 0.882 & 448.18 \\
335 & $a(335)=1.2948 \times \operatorname{EXP}[0.0031 \times \mathrm{Fn}(335)]$ & 0.891 & 491.21 \\
355 & $a(335)=0.0103 \times \operatorname{Fn}(335)+0.3597$ & 0.864 & 381.80 \\
& $a(355)=0.9381 \times \operatorname{EXP}[0.0037 \times \mathrm{Fn}(355)]$ & 0.885 & 460.17 \\
& $a(355)=0.0083 \times \operatorname{Fn}(355)+0.3781$ & 0.864 & 381.84 \\
\hline
\end{tabular}


No.41271343; No.41030751; No.41103047), the Open research fund of key laboratory of digital earth, the Center for earth observation and digital earth, the Chinese Academy of Sciences (No.2012LDE009), the Natural Science Funds of Provincial Universities (12KJB170005), the Priority Academic Program Development of Jiangsu Higher Education Institutions. The authors would also like to thank the two anonymous reviewers for their useful comments and suggestions.

\section{REFERENCES}

Andersson CA, Bro R, 2000. The n-way toolbox for MATLAB. Chemometr. Intell. Lab. 52:1-4.

Arrigo KR, Brown CW, 1996. The impact of chromophoric dissolved organic matter on UV inhibition of primary productivity in the open ocean. Mar. Ecol.-Prog. Ser. 140:207-216.

Bachmann RW, Hoyer MV, Canfield DE, 2000. The potential for wave disturbance in shallow Florida lakes. Lake Reserv. Manage. 16:281-291.

Bidigare RR, 1989. Potential effects of UV-B radiation on marine organisms of the southern ocean: distributions of phytoplankton and krill during austral spring. Photochem. Photobiol. 50:469-477.

Bontempi P, Davis S, Del Castillo C, Roelke D, Davis S, Winemiller KO, 2003. Transformation of allochthonous dissolved organic carbon in a tropical black water river as measured by fluorescence analysis application to food web ecology. Society of Photo-optical Instrumentation Engineers Publ. Available from: http://wfsc.tamu.edu/winemiller/lab/Bontempi-etal-SPIE03.pdf

Bricaud A, Morel A, Prieur L, 1981. Absorption by dissolved organic matter in the sea (yellow substance) in the UV and visible domain. Limnol. Oceanogr. 26:43-53.

Bro R, 1997. PARAFAC: tutorial and applications. Chemometr. Intell. Lab. 38:149-171.

Carder KL, 1991. Reflectance model for quantifying chlorophyll a in the presence of productivity degradation products. J. Geophys. Res. 96:20599-20611.

Carder KL, Chen FR, Lee ZP, Hawes SK, Cannizzaro JP, 2003. MODIS ocean science team algorithm theoretical basis document (ATBD 19, Case 2 Chlorophyll a). University of South Florida Publ., St. Petersburg: 67 pp.

Carder KL, Stewardg RG, Harvey R, Ortner PB, 1989. Marine humic and fulvic acids: their effects on remote sensing of ocean chlorophyll. Limnol. Oceanogr. 34:68-81.

Chen W, Westerhoff P, Leenheer J, Booksh K, 2003. Fluorescence excitation: emission matrix regional integration to quantify Spectra for dissolved organic matter. Environ. Sci. Technol. 37:5701-5710.

Coble PG, 1996. Characterization of marine and terrestrial DOM in seawater using excitation-emission matrix spectroscopy. Mar. Chem. 51:325-346.

Coble PG, Del Castillo CE, Avril B, 1998. Distribution and optical properties of CDOM in the Arabian Sea during the 1995 Southwest Monsoon. Deep-Sea Res. Pt. II 45:2195-2223.

Donard OFX, Lamotte M, Belna C, Ewald NM, 1989. High sensitivity fluorescence spectroscopy of Mediterranean waters using a conventional or a pulsed laser excitation source. Mar. Chem. 27:117-136.
Ferrari G M, Tassan S, 1991. On the accuracy of determining light absorption by "yellow substance" through measurements of induced fluorescence. Limnol. Oceanogr. 36:777786.

Fu QP, Wu FC, Liu CQ, Li W, 2007. Three-dimensional excitation emission matrix fluorescence spectroscopy of dissolved organic matter from Chinese highland lakes. Oceanol. Limnol. Sin. 38:512-520.

Green S, Blough N, 1994. Optical absorption and fluorescence properties of chomophoric dissolved organic matter in natural waters. Limnol. Oceanogr. 39:1903-1916.

Harshman RA, Lundy ME, 1994. Parafac parallel factor analysis. Comput. Stat. Data An. 18:39-72.

Helms JR, Stubbins A, Ritchie JD, Minor EC, 2008. Absorption spectral slopes and slope ratios as indicators of molecular weight, source, and photobleaching of chromophoric dissolved organic matter. Limnol. Oceanogr. 53:955-969.

Hoge FE, Vodacek A, Blough NV, 1993. Inherent optical properties of the ocean: retrieval of the absorption coefficient of chromophoric dissolved organic matter from fluorescence measurements. Limnol. Oceanogr. 38:1394-1402.

Keith DJ, Yoder JA, Freeman SA, 2002. Spatial and temporal distribution of colored dissolved organic matter (CDOM) in Narragansett Bay, Rhode Island: implications for phytoplankton in coastal waters. Estuar. Coast. Shelf S. 55:705717.

Kieber RJ, Willey JD, Whitehead RF, 2007. Photobleaching of chromophoric dissolved organic matter(CDOM) in rainwater. J. Atmos. Chem. 58:219-235.

Kowalczuk P, Olszewski J, Darecki M, 2005. Empirical relationships between colored dissolved organic matter (CDOM) absorption and apparent optical properties in Baltic Sea. Int. J. Remote Sens. 26:345-370.

Laurion I, Catalan VM, Psenner RJ, Sommaruga R, 2000. Attenuation of ultraviolet radiation in mountain lakes: factors controlling the among- and within-lake variability. Limnol. Oceanogr. 45:1274-1288.

Lee ZP, Carder KL, Arnone RA, 2002. Deriving inherent optical properties from water color: a multiband quasi-analytical algorithm for optically deep waters. Appl. Optics 41:57555772.

Leenheer JA, Croué JP, 2003. Characterizing aquatic dissolved organic matter. Environ. Sci. Technol. 37:19-26.

McKnight DM, Boyer EW, Westerhoff P, 2001. Spectrofluorometric characterization of dissolved organic matter for indication of precursor organic materials and aromaticity. Limnol. Oceanogr. 46:38-48.

Mobed JJ, Hemmingsen SL, Autry JL, 1996. Fluorescence characterization of IHSS humic substances: total luminescence spectra with absorbance correction. Environ. Sci. Technol. 30:3061-3065.

Mopper K, Zhou XL, Kieber RJ, Sikorski RJ, Jones RD, 1991. Photochemical degradation of dissolved organic carbon and its impact on the oceanic carbon cycle. Nature 353:60-62.

Murphy KR, Stedmon CA, David BT, Waite C, Ruiz GM, 2008. Distinguishing between terrestrial and autochthonous organic matter sources in marine environments using fluorescence spectroscopy. Mar. Chem. 108:40-58.

Nelson N, Siegela D, Carlsona CA, William CS, Smethie M, Khatiwala JS, 2007. Hydrography of chromophoric dis- 
solved organic matter in the North Atlantic. Deep-Sea Res. 54:710-731.

Patel-Sorrentino N, Mounier S, Benaim JY, 2002. Excitationemission fluorescence matrix to study $\mathrm{pH}$ influence on organic matter fluorescence in the Amazon basinrivers. Water Res. 36:2571-2581.

Qin BQ, Hu WP, Chen WM, 2004. Process and mechanism of environment changes of the Taihu Lake. Science Press.

Repetad J, Hartman N, John S, 2004. Structure elucidation and characterization of polychlorinated biphenyl carboxylic acids as major constituents of chromophoric dissolved organic matter in seawater. Environ. Sci. Technol. 38:53735378.

Reuter R, Diebel-Langhor D, Dorref F, Hengstermann T, 1986. Airborne laser fluorosensor measurements of Gelbstoff, $\mathrm{p}$. 58. In: H. Grass et al. (eds.), The influence of yellow substances on remote sensing of sea-water constituents from space. II. GKSS Research Centre ed.

Schindledr W, Jefferson-Curbt P, Parker IS, Staintok M, 1996. Consequences of climate warming and lake acidification for UV-B penetration in North American boreal lakes. Nature 379:705-708.

Sleighter RL, Hatcher PG, 2008. Molecular characterization of dissolved organic matter (DOM) along a river to ocean transect of the lower Chesapeake Bay by ultrahigh resolution electrospray ionization Fourier transform ion cyclotron resonance mass spectrometry. Mar. Chem. 110:140-152.

Stedmon CA, 2007. Photochemical production of ammonium and transformation of dissolved organic matter in the Baltic Sea. Mar. Chem. 104:227-240.

Stedmon CA, Markager S, 2005a. Resolving the variability of dissolved organic matter fluorescence in a temperate estuary and its catchment using PARAFAC analysis. Limnol. Oceanogr. 50:686-697.

Stedmon CA, Markager S, 2005b. Tracing the production and degradation of autochthonous fractions of dissolved organic matter using fluorescence analysis. Limnol. Oceanogr. 50:1415-1426.

Stedmon CA, Markager S, Bro R, 2003. Tracing dissolved organic matter in aquatic environments using a new approach to fluorescence spectroscopy. Mar. Chem. 82:239-254.

Toole DA, Siegel DA, 2004. Light-driven cycling of dimethylsulfide (DMS) in the Sargasso Sea: closing the loop. Geophys. Res. Lett. 31:L09308.

Twardowski MS, Boss E, Sullivan JM, Donaghay PL, 2004. Modeling the spectral shape of absorption by chromophoric dissolved organic matter. Mar. Chem. 89:69-88.

Vernet M, Whitehead K, 1996. Release of ultraviolet-absorbing compounds by the red-tide dinoflagellate Lingulodinium polyedra. Mar. Biol. 127:35-44.

Warnock RE, Gieskes WC, 1999. Regional and seasonal differences in light absorption by yellow substance in the Southern Bight of the North Sea. J. Sea Res. 42:169-178.

Zepp RG, Callaghan TV, Erickson DJ, 1998. Effects of enhanced ultraviolet radiation on biogeochemical cycles. J. Photoch. Photobio. B 46:69-82.

Zhang YL, Qin BQ, Zhang L, 2005. Spectral absorption and fluorescence of chromophoric dissolved organic matter in shallow lakes in the middle and lower reaches of the Yangtze River. J. Freshwater Ecol. 20:451-459.

Zhang YL, Qin BQ, Zhu GW, 2007a. Chromophoric dissolved organic matter (CDOM) absorption characteristics in relation to fluorescence in Lake Taihu, China, a large shallow subtropical lake. Hydrobiologia 581:43-52.

Zhang YL, Zhang EL, Liu ML, Whang X, Qin BQ, 2007b. Variation of chromophoric dissolved organic matter and possible attenuation depth of ultraviolet radiation in Yunnan Plateau lakes. Limnology 8:311-319.

Zhao QH, Qin BQ, 2008. Mechanisms and characteristics of spatial distribution of colored dissolved organic matter in Taihu Lake between summer and winter. China Environ. Sci. 28:289-293. 